\title{
Publisher Correction: RIPK1 gene variants associate with obesity in humans and can be therapeutically silenced to reduce obesity in mice
}

Denuja Karunakaran (D, Adam W. Turner, Anne-Claire Duchez, Sebastien Soubeyrand (D), Adil Rasheed (D), David Smyth, David P. Cook (D), Majid Nikpay, Joshua W. Kandiah, Calvin Pan (D), Michele Geoffrion, Richard Lee (D), Ludovic Boytard, Hailey Wyatt, My-Anh Nguyen, Paulina Lau, Markku Laakso iD, Bhama Ramkhelawon (iD, Marcus Alvarez, Kirsi H. Pietiläinen (D), Päivi Pajukanta (D), Barbara C. Vanderhyden (D), Peter Liu, Scott B. Berger, Peter J. Gough, John Bertin, Mary-Ellen Harper (D), Aldons J. Lusis (D), Ruth McPherson (D) and Katey J. Rayner (D)

Correction to: Nature Metabolism https://doi.org/10.1038/s42255-020-00279-2, published online 28 September 2020.

In the version of this article initially published, author Katey J. Rayner had affiliation numbers 1,13; the correct affiliation numbers are 1,12 . The error has been corrected in the HTML and PDF versions of the article.

Published online: 8 October 2020

https://doi.org/10.1038/s42255-020-00309-Z

(C) The Author(s), under exclusive licence to Springer Nature Limited 2020 